\section{Dorian Gray mice exposed}

SIR - Congratulations on the wonderful April fool's story by Robin A. Weiss on Dorian Gray mice (Nature 362, 411; 1993). I have assigned it to my graduate students for review and opinions. I wonder what they will make of it. I also left it on the desk of a young colleague who directs a vector core facility and designs retroviral vectors, with the request to put the tith gene under various tissue specific promoters so that we may keep certain parts of male or female anatomy forever young.

\section{Ollvera J. Finn}

W1143 Biomedical Science Tower, University of Pittsburgh,

School of Medicine,

Pittsburgh,

Pennsylvania 15261, USA

SIR -- As a regular reader of Nature in a non-British country with a less-developed sense of humour, and admitting that I may be at the negative end of the fun spectrum, I suggest that the article "Dorian Gray mice" will not only provoke smiles from biologists but may have more severe consequences. Indeed, in Germany there is in reality a group calling itself the "Genethisches Netzwerk" which tries to swamp the German population with accusations not very different from that of preprogrammed death.

Nature is known as a scientific publication and not as a magazine for the entertainment of its readers. Also, I am afraid that among serious people the distinction between fact and fiction will be blurred. Nature is read by many journalists who may not be able to distinguish between real and fictional data and may therefore be misled.

Peter Starlinger

Institute für Genetik,

Universität zu Köln

Weyertal 121,

5000 Köln 41, Germany

SIR - We read with interest the article on Dorian Gray mice. As froggies, we appreciate the fascinating possibilities of increasing the size of these charming little animals. But the paper by Ariellos et al. was misquoted. In fact, it is notorious that this marvellous work was edited by Chatqui-expire, the famous scholar of the soul in one of its best monographs, The Tempest.

C. Larsen

A. Tsapis

M. Lanotte

T. Soussi

R. Berger

Unité 301 INSERM,

Institut de Génétique Moléculaire,

27 rue Juliette Dodu,

75010 Paris, France
SIR - As usual in the field of molecular biology, the origins of experiments are forgotten. Weiss's masterly exposition of ageless mice research has forgotten my own signal contributions. After many a summer in Messina, I not only discovered phagocytosis but I also formulated the proposition that ageing was due to the interaction of phagocytes with intestinal bacterial. My swan song - so to speak was to propose the antidote: yoghurt ${ }^{1}$.

Elie Metchnikoff

As communicated to

G. Weissmann,

Department of Medicine,

NYU Medical Center

550 First Avenue,

New York, New York 10016, USA

1. Metchnikoff. E. Z. Dannon Res. 3, 1143 (1992)

SIR - As apoptosis is a common mechanism of the death of T cells, perhaps Robin Weiss's article should have been entitled "Earl Grey mice".

\section{John Moore}

Aaron Diamond AIDS Research Center, 4551 st Avenue, Seventh Floor, New York, New York 10016, USA

SIR - Weiss's article about immortal transgenic mice caused great interest among staff and students at this university. Several people were seen looking frantically for more details on the subject for their next seminars, while others enthusiastically held forth to their students on this new and exciting matter. Still others were already trying to get cDNA probes for longevin and tithonin, with the intention of performing widespread screening of all kinds of libraries. In addition, at least two grant applications were hastily submitted in the first week of April. This was not due to naivety on the part of Spanish researchers and students - the equivalent in Spain of April fool's day is Innocents' Day on 28 December. So we were caught by surprise as we do not expect this kind of joke to be played in spring. In the end we all had a good laugh because it was a joke, right?

Yolanda S. López-Boado

Fernando Segade

Departmento de Biología Funcional,

Universidad de Oviedo

33071 Oviedo, Spain

The book review by Orlando Belpaese on page 422 was also an April Fool's joke Editor, Nature.

Letters submitted for Correspondence should be typed, double-spaced, on one side of the paper only.

\section{Dating ice cores}

SIR - The data obtained on ice cores from the European (GRIP) and the US (GISP2) drilling projects are of great interest to the palaeoclimatic community. The first papers regarding timescales for the past 40,000 years have been published in Nature ${ }^{1-3}$. The main purpose of this correspondence is to convey to the scientific community that a shared effort now exists to compare and refine the dating of these cores $^{2}$. The timescales were constructed by each group independently by counting successive annual layers by various methods. The dates of the two cores back to 14,500 calendar yrs BP agree exceptionally well within expected error (250 years) where counting was continuous ( $\Delta T=230$ years) at the start of the Bølling (14.5 kyr ago). Below this, spot counting and interpolation leads to divergence in the timescales. This deviation increases progressively to $40 \mathrm{kyr}$ where the difference approaches $5 \mathrm{kyr}$. However, the scales still remain consistent within esitmated errors $( \pm 3.5 \mathrm{kyr})$. At a recent GRIP/GISP2 workshop, the US and European scientists responsible for the dating in the two projects exchanged information regarding the age dating of the cores leading to the following:

(1) The present difference between the timescales is essentially due to the preliminary character of the work. The data were published before complete analysis of the age-depth relationship because of their importance to the scientific community.

(2) A joint GISP2/GRIP paper on dating to $40 \mathrm{kyr} \mathrm{BP}$ is to be finalized during a common workshop and it is the intention of those involved that a joint paper on the dating of the entire record back to at least 140 kyr will be completed.

As chairpersons of the GISP2/GRIP dating committees, we stress the importance of the independent dating of the ice cores as it is a prerequisite for the meaningful comparison with other palaeorecords in a truly consistent global way. These relationships will allow us to develop our understanding of global climate change and of the climate forcing parameters that drive it.

C. U. Hammer

Niels Bohr Institute of Physics,

Astronomy and Geophysics,

University of Copenhagen,

Haraldsgade 6

DK 2200 Copenhagen N, Denmark

D. A. Meese

USA Cold Regions Research

and Engineering Laboratory,

72 Lyme Road,

Hanover,

New Hampshire 03755, USA

1. Johnsen, S. et al. Nature 359, 311-313 (1992)

2. Taylor, K. et al. Nature 361. 432-436 (1993).

3. Alley, R. et al. Nature 362, 527-529 (1993) 